\title{
Surface identification of undermined spaces with the use of soil radon emanometry
}

\section{Erik ANDRÁSSY ${ }^{1}$ (D) Andrej MOJZEŠ ${ }^{1, *}$ (D) Ema NOGOVÁ ${ }^{1,2}$ (D), Ondrej ČANGEL ${ }^{3}$}

${ }^{1}$ Department of Engineering Geology, Hydrogeology and Applied Geophysics, Faculty of Natural Sciences, Comenius University, Mlynská dolina, Ilkovičova 6, 84215 Bratislava, Slovak Republic

${ }^{2}$ Geophysical Division, Earth Science Institute of the Slovak Academy of Sciences, Dúbravská cesta 9, 84005 Bratislava, Slovak Republic

${ }^{3}$ Institute of Geodesy and Cartography, Chlumeckého 4, Bratislava, Slovak Republic

\begin{abstract}
Several surface geophysical methods were used to study the displays of undermined spaces in their physical fields and to try to distinguish undermined from nonundermined parts of underground mining area. The studied area of the Ćáry lignite mine in the Western Slovakia represents an actively subsided place with high risk to the population. Despite very low radioactivity and relatively high gas permeability of building geological formations, the results of soil radon emanometry show the possibility of radon gas accumulation inside the undermined spaces, but their permanent subsidence causes loosing of overlying material and escape of radon gas. The boundaries (edges) of undermined and sunken areas were identified as the only places with increased values of ${ }^{222} \mathrm{Rn}$ activity, probably due to the presence of vertical supporting mine walls allowing radon gas accumulation and upward movement. Thus, the soil radon emanometry clearly indicates the borders between undermined or sunken and non-undermined parts.
\end{abstract}

Key words: soil radon emanometry, gamma spectrometry, underground corridors, undermined area, subsidence

\section{Introduction}

The displays of subsidence in the undermined areas by human activity were studied within the VEGA 1/0462/16 project "Solution of actual problems in geophysical and geodetic detection of underground cavities in environmental and archaeological applications" between the years 2016 and 2019 with the use of exploratory research methods of applied geophysics. Such

\footnotetext{
${ }^{*}$ corresponding author: e-mail: andrej.mojzes@uniba.sk
} 
artefacts of human activity are present in multiple places in Slovakia, especially in the context of the past, but also nowadays continuous mining action with the purpose of underground mining and quarrying of non-renewable resources, primarily of brown coal is performed. Typical are the areas of the brown coal basin in the Horná Nitra region near towns such as Prievidza, Handlová, and Nováky, and the Southern Slovak brown coal basin near the town of Modrý Kameň. Another brown coal mining field is near Kúty, the Záhorie region, but it is of much smaller range. In all of these areas, complicated geological structure and insufficient technological security led to subsidence due to a collapse of ceiling constructions of underground corridors in the form of caving ruptures, or pings. These collapses represent a life-threatening risk (sometimes sudden) and allow no human activity on the surface of the undermined locations. These movements can often activate long after the mining had stopped due to extreme meteorological conditions, e.g. intense rainfall seasons. The subsidence activity can be detected and monitored in a satisfying manner with exact geodetic methods $(C z i k h a r d t ~ e t$ al., 2017) and surface geophysical methods (Negri et al., 2015). The complex of these research methods (microgravimetry, geoelectrics, ground penetrating radar (GPR), shallow seismic method, gamma spectrometry, and soil radon emanometry) was used during a detailed research in two locations in the stoping ground areas, Koš near Prievidza and Č́ry near Kúty. The aim was to identify and offer geophysical characteristics of the risky places with the presence of new underground cavities as the consequence of older subsidence activities (Zahorec et al., 2021). This contribution is focused on the evaluation of the application of only one of the mentioned geophysical research methods - to assess the options of soil radon emanometry during the surface identification of underground mining corridors in the Cáry location. The radon emission problematic of the stoping ground mining areas in the process of their stabilization is the study subject for two reasons - in regards to population protection from radon risks, and for monitoring the overlain spaces sinking processes (Wysocka et al., 2018).

\section{Study area and geological setting}

Near Kúty, a town in Senica region in Western Slovakia, close to Cáry village, the mining field of the Hornonitrianske bane Prievidza, a.s. is located 
(Figs. 1, 2), which is a place where the displays of subsidence in the stoping ground areas by human activity were studied.

The studied area is situated in the geological unit of the Vienna Basin, which represents an overlain Neogene structure on the Bohemian Mas-

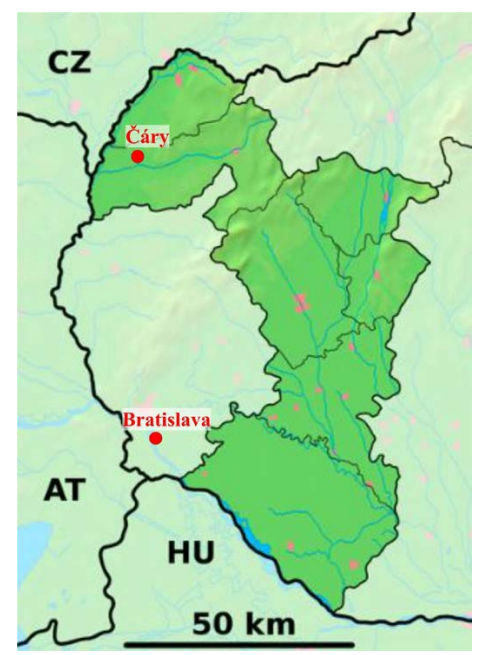

Fig. 1. Localization of the Cáry village within the Trnava self-governing region (Andrássy, 2020).

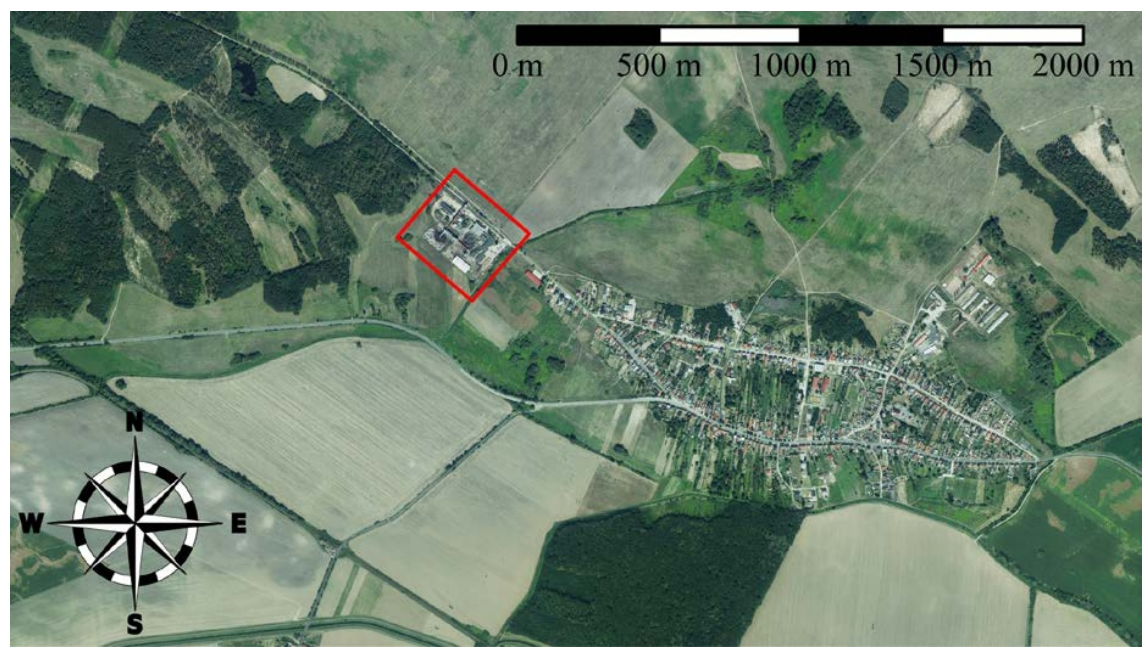

Fig. 2. Studied area showed in an orthophoto image of the Cáry village surroundings (GCI \& NFC, 2017-2019). 
sif, Western Carpathians, and Eastern Alps, which border the basin (e.g., Šamajová et al., 2019). A more detailed geological structure of the studied area is composed of three parts - aeolian sediments, fluvial sediments, and the Gbely Formation (Fig. 3).

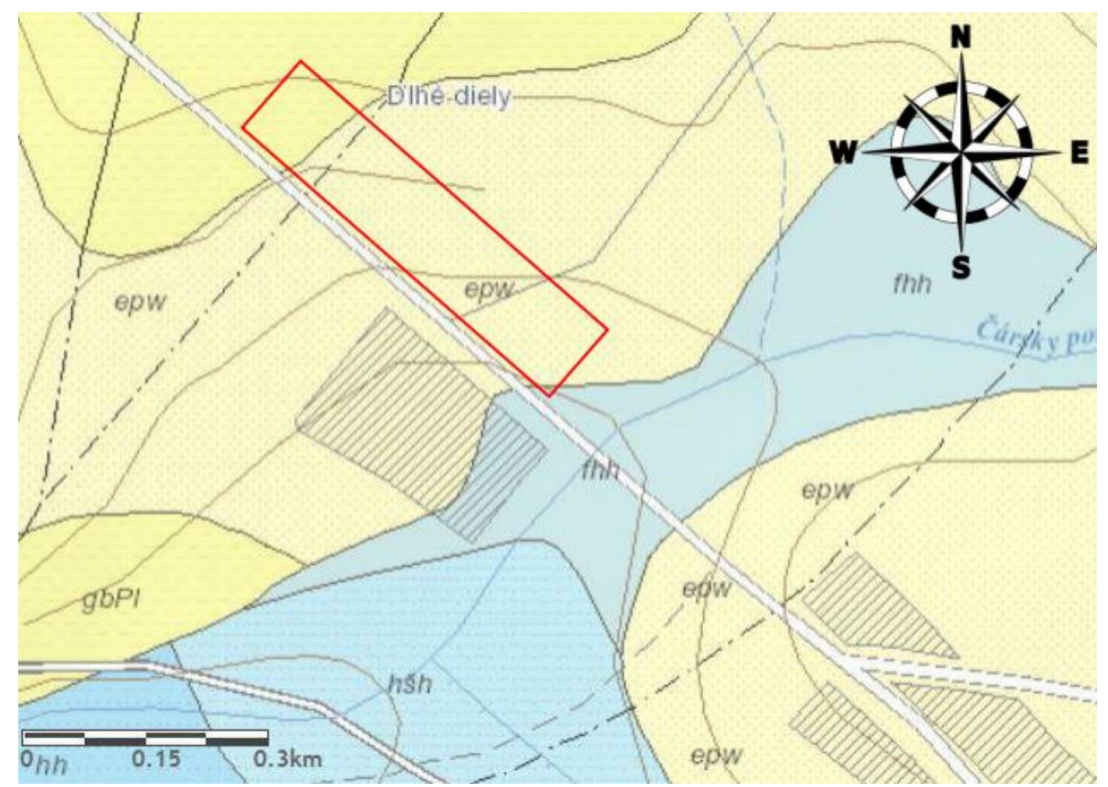

Geological map legend:

epw-aeolic sediments

gbPl - the Gbely Formation

fhn - fluvial sediments

- built-up area

Fig. 3. Geological map of the researched area with the marked area of interest (Andrássy 2020).

Aeolian sediments create dunes of various forms; mostly loaf-like at the base. Accumulations are built by medium, but mostly fine-grained yellow and light-brown wind-blown sand, which is often secondarily bleached and sporadically layered. The layering is often represented by cross layering and emphasized by granular structure and a ferruginous element (Fordinál et al., 2012).

Fluvial sediments are represented by sediments of river and creek floodplains. Postglacial alluviums of overbank deposits make up an essential part of fine-grained sedimentary surface cover of sandy-gravel formation of 
river bottom accumulations or they fill the creek valley bottoms in their whole cross profile. The base of formation is mostly composed of clayey gray loams (which can be locally replaced by gray-green clayey gley horizon), clayey sands, and towards an active flow also by resedimented gravels and sands - from the upper positions of the bottom accumulation. Clayey loams are often overlapped by a dark grey - black humic horizon of buried alluvial-plain loams, which is overlied by silty, clayey and humic deposits of alluvial plain facies (Fordinál et al., 2012).

The Gbely formation, from a lithologic perspective, is composed of greengrey clay and sand with many scattered calcareous concretions. The sand, mostly in the form of lens, is yellow and green coloured; the bottom part of the formation is of blue hues; clay and sand are calcareous; sand positions prevailing over clays. The formation was deposited in a lacustrine, shallow

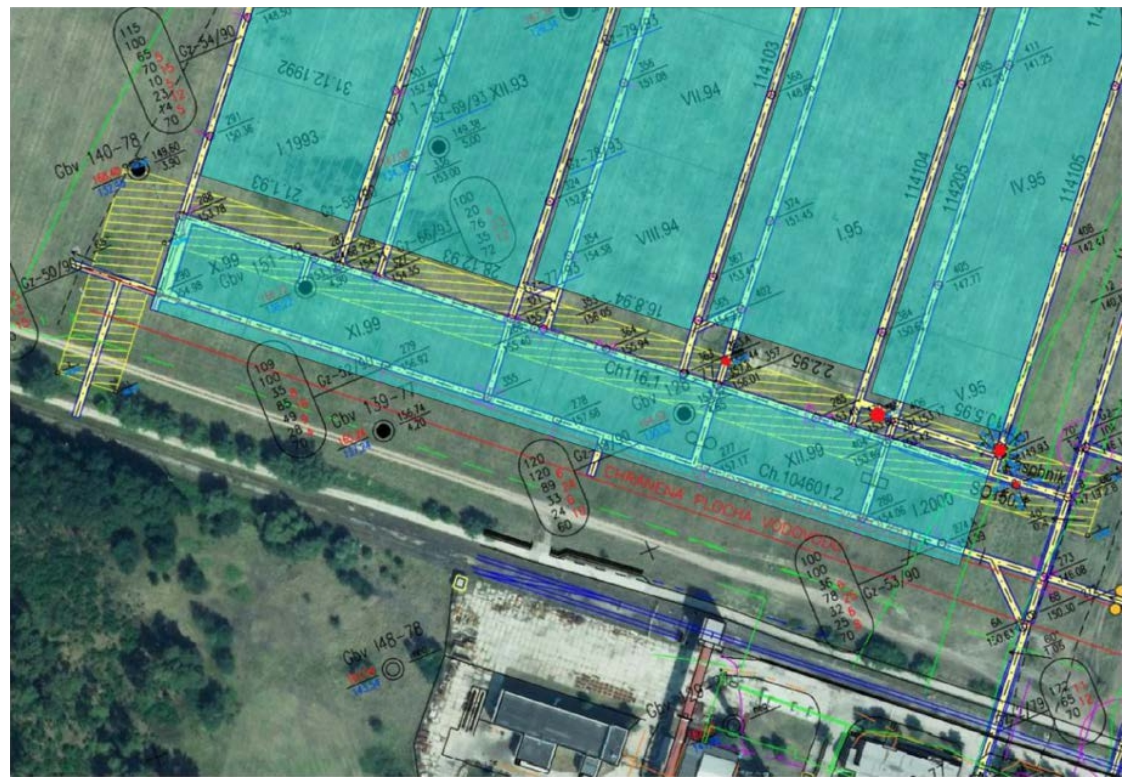

Fig. 4. Map showing the mine's plan (Čangel, 2019). Explanatory notes: Boreholes are marked by black circles; the position of the water-pipe is marked by a green dashed line; the protected area of the water pipe is marked by a red line; mined spaced are marked by a cyan hatched area; exploratory mining corridors are marked by white strips; concrete support is marked by a blue double line; the yellow hatched area marks those parts where agricultural machinery is forbidden; surface pits (pings) created after the swamp of mining spaces are marked by red circles. 
environment, or in a river floodplain (Fordinál et al., 2012).

Lignite is being actively mined in the locality and for that purpose, underground exploratory corridors are built in the area of interest (Fig. 4). Individual corridors are of trapezoid shape, with the width of the lower base being $2.9 \mathrm{~m}$ and the height being $2.3 \mathrm{~m}$. The corridors are supported with steel profiles that are spaced by $0.6 \mathrm{~m}$. The ceiling and corners of the corridors are, besides the steel profiles, also reinforced by wood sheets (the ceiling is sheeted fully; the sides in a chessboard structure). Sides of the corridor, inclined shafts no. 1 and 2 (corridors in the lower right part of Fig. 4) are supported by $0.5 \mathrm{~m}$ wide concrete blocks; the ceiling is supported by steel profiles and a $7 \mathrm{~cm}$ wide reinforced concrete rod. On the map (Fig. 4), the concrete support is marked with a blue double line in the corridor's area (Čangel, 2019).

The levelling measurements in corridors and on the surface showed the depth difference between them and subsequently the exact depth was calculated. The depth of corridors is from 7 to $12.7 \mathrm{~m}$ below the surface. GPR method was implemented in early July 2018, the method confirmed the depth of the corridors (Čangel, 2019).

\section{Method used}

Method of soil radon emanometry serves for identifying the presence of radon in the soil air on the basis of alpha radiation detection (Mareš et $a l ., 1990)$. The determination of ${ }^{222} \mathrm{Rn}$ in soil air is based on detection of alpha radiation emitted during decay of radon and/or its daughter products' nuclei by appropriate detectors (Mojzeš, 2012). The advantage of measuring emanation with a portable emanometer is that it provides results directly in the terrain. The emanometer used was LUK 3R (manufacturer Speciální měřicí metody, Prague) that operates on the basis of a scintillation counter, in which a sample of soil air is inserted into.

Instead of a stable detection counter chamber, replaceable aluminium or glass inserts with the silver activated zinc sulphide $\mathrm{ZnS}(\mathrm{Ag})$ coating, also called Lucas chambers, were used. Thanks to that, the value of the background activity in the chamber from the attached radon decay products from the previously measured soil air sample is low, therefore the ratio of useful signal to the background increase (Mojzeř, 2012). 


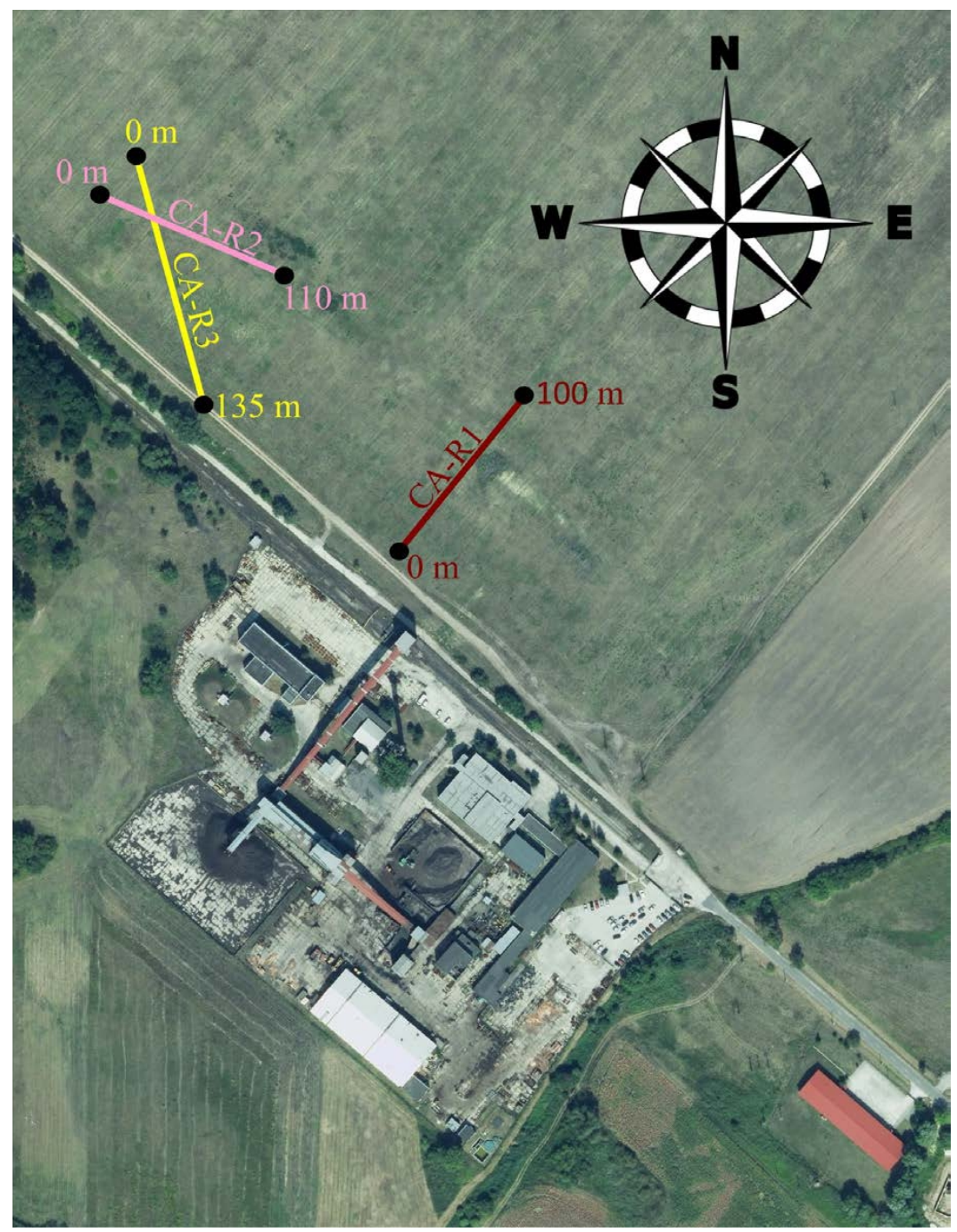

Fig. 5. The orientation of emanometric profiles (GCI \& NFC, 2017-2019).

Data collecting was performed in a static manner, an individual soil air sample collected from depths between 0.6 and $1 \mathrm{~m}$ was inserted into the measuring chamber. The soil air sampling was performed using a $163 \mathrm{ml}$ rinsing syringe JANETTE through a mechanical dust filter and dryer. The most important is thorough sealing of the sampling probe, lest soil air dilute 
with atmospheric air, sampling of optimal $(163 \mathrm{ml})$ amount of air from the same depth $(0.8 \mathrm{~m})$, and sealing of the whole system. If otherwise, it would be necessary to make adjustments.

The data collecting itself was performed along three profiles (CA-R1 on $5^{\text {th }}$ May 2019 and CA-R2 and CA-R3 on $26^{\text {th }}$ September 2019), position of which was chosen so that they should go over the undermined and nonundermined areas of the location (Fig. 5). The soil air samples were taken using the lost tip drilling method. Individual profiles were not of the same length; profile CA-R1 was $95 \mathrm{~m}$ long, profile CA-R2 was $110 \mathrm{~m}$ long, and the last profile, CA-R3, was $135 \mathrm{~m}$ long.

The processing of the measured data was based on transferring radon $\left({ }^{222} \mathrm{Rn}\right)$ activity concentration data in $\mathrm{kBq} \cdot \mathrm{m}^{-3}$ from the inner memory of the device to a computer, and their reviewing in a common spreadsheet editor (Golden Software Grapher). In case that the sampling of soil air was not performed from the nominal depth of $0.8 \mathrm{~m}$ or the volume of the sample was not the nominal $163 \mathrm{ml}$, those values were recalculated into the stated nominal values.

Final values of the ${ }^{222} \mathrm{Rn}$ activity concentration were visualized in a form of a graph along the measured profile (Figs. 6, 8 and 10).

The measurement of uranium was performed in September 2018 with gamma spectrometer PGIS-2 (manufacturer Pico Envirotec, Ltd., Canada). The device is able to collect concentration of uranium data every second. Spacing between profiles was $2.5 \mathrm{~m}$, every profile was approximately $100 \mathrm{~m}$ long and the width of the measured area was $484 \mathrm{~m}$ (Andrássy, 2020).

\section{Results}

On the CA-R1 profile (Fig. 6), which is $95 \mathrm{~m}$ long, 10 samples with irregular steps were taken. The part of the profile in between $41-66 \mathrm{~m}$ lies in the forbidden area (see yellow hachure in Fig. 4). Visually, it is evident in topography that the part of the profile in between $20-80 \mathrm{~m}$ is subsided in comparison with its beginning and end. The beginning of the profile lies near the road where the environment is not suitable for collecting samples of soil air. The first point was measured on the $5 \mathrm{~m}$ station in the non-undermined part and the radon concentration value of $7 \mathrm{kBq} \cdot \mathrm{m}^{-3}$ was registered. Three places with increased radon concentration - on 15, 60, and $85 \mathrm{~m}$ (Fig. 6) were 


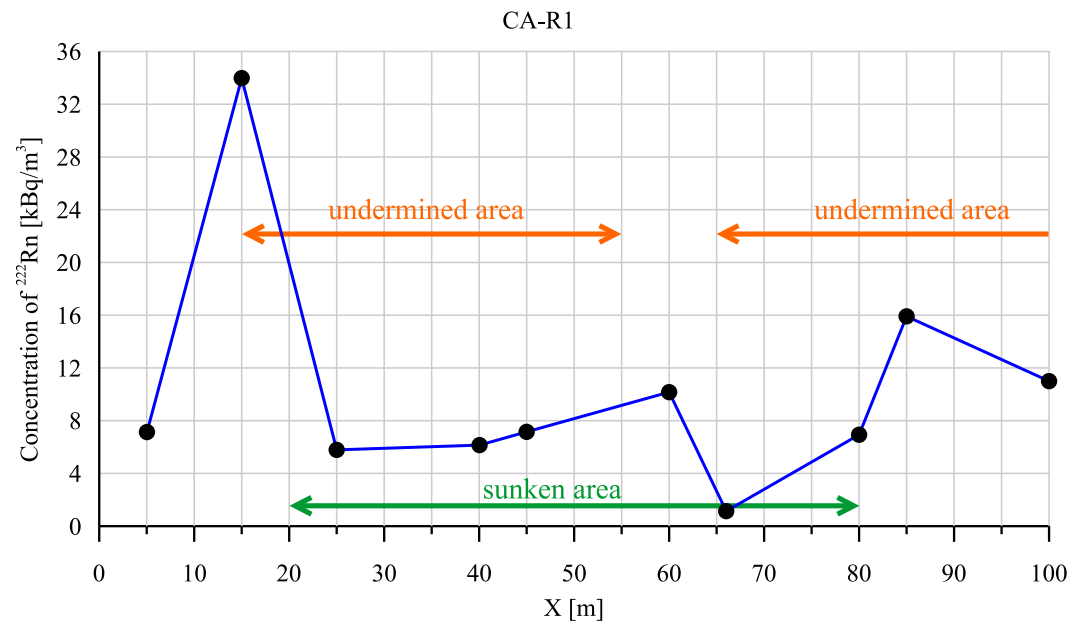

Fig. 6. Rn concentration values along CA-R1 profile (Andrássy, 2020).

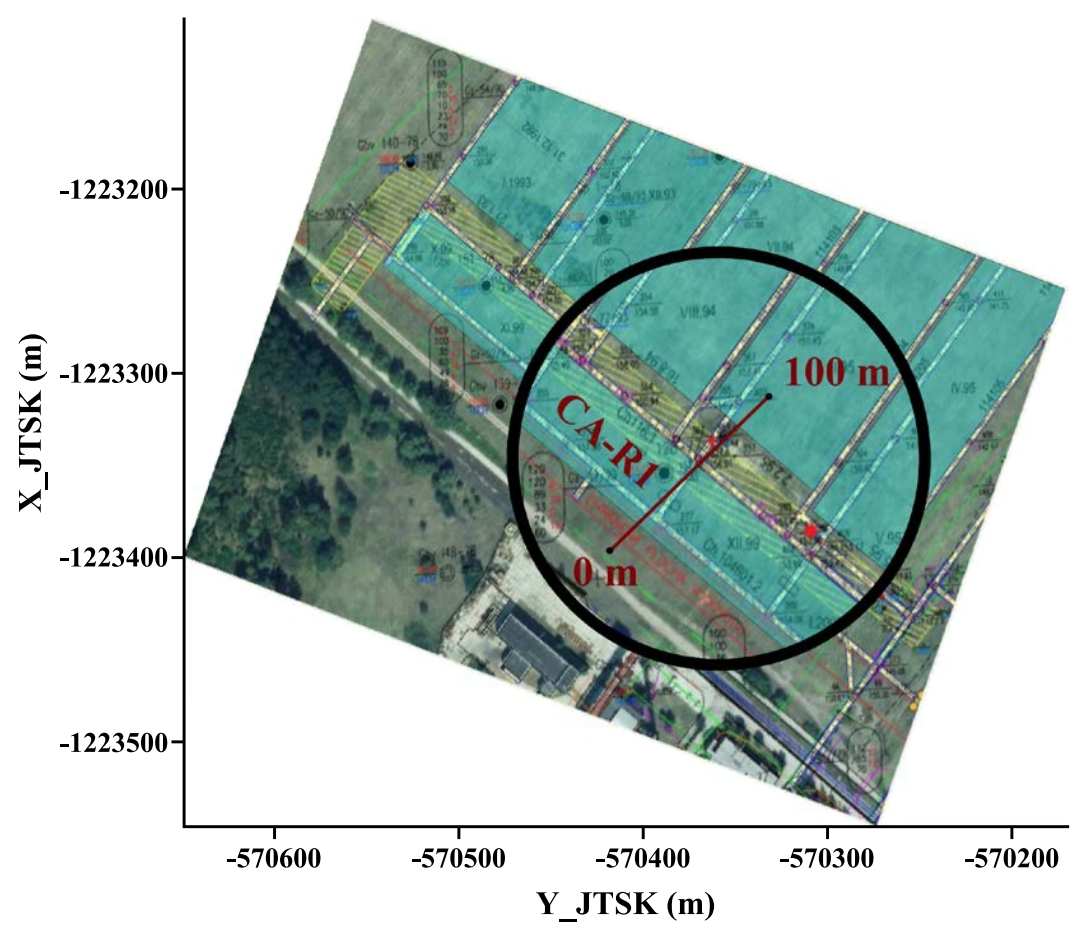

Fig. 7. Map showing the mine plan with an applied CA-R1 profile (亡̌angel, 2019; edited). 
recorded along the profile. The highest value, $34 \mathrm{kBq} \cdot \mathrm{m}^{-3}$, was recorded on the 15 meter and fits perfectly with the SW boundary of undermined space (Figs. 7 and 4). Next increased value of $10 \mathrm{kBq} \cdot \mathrm{m}^{-3}$ on $60 \mathrm{~m}$ position fits again perfectly with the NE boundary of the same undermined space (Figs. 7 and 4). The lowest value of $1 \mathrm{kBq} \cdot \mathrm{m}^{-3}$ on $66 \mathrm{~m}$ is probably in direct relation with the ping situated on $63 \mathrm{~m}$ which causes ground air ventilation and is the reason for extremely low radon concentration. Although the SW boundary of another block of undermined space located on $70 \mathrm{~m}$ (Figs. 7 and 4) is not indicated by higher value of radon concentration, it seems that the visual end of sunken area is again represented by increased value of $16 \mathrm{kBq} \cdot \mathrm{m}^{-3}$ on $85 \mathrm{~m}$.

CA-R2 profile (Fig. 8) is $110 \mathrm{~m}$ long with 11 irregularly taken soil air samples. The part of profile in between 10-90 $\mathrm{m}$ lies in the forbidden area (see yellow hachure in Fig. 4), which should be the sunken area, but the edges of terrain subsidence can be indistinctly seen only in the part between 70 and $90 \mathrm{~m}$. The first point was measured in the non-undermined part and the radon concentration value of $8 \mathrm{kBq} \cdot \mathrm{m}^{-3}$ was registered (Figs. 9 and 4). As the profile is crossing exactly the NW corner of the undermined space by three measuring stations and all of them are very close to the boundary walls, the registered values of radon concentration belong to the higher ones: nearly $25 \mathrm{kBq} \cdot \mathrm{m}^{-3}$ on $40 \mathrm{~m}$ (entering the undermined area), $27 \mathrm{kBq} \cdot \mathrm{m}^{-3}$ on $50 \mathrm{~m}$ and $35 \mathrm{kBq} \cdot \mathrm{m}^{-3}$ on $60 \mathrm{~m}$ (leaving the undermined area). Another entry in the undermined area fits well with higher value of $21 \mathrm{kBq} \cdot \mathrm{m}^{-3}$ on $100 \mathrm{~m}$. The stations situated on 70,80 and $90 \mathrm{~m}$ lie in the indistinctly visible sunken area with responding low radon concentration values ( 15 and $14 \mathrm{kBq} \cdot \mathrm{m}^{-3}$ ), except for the $80 \mathrm{~m}$ station, whose high value of nearly $35 \mathrm{kBq} \cdot \mathrm{m}^{-3}$ could be the display of the real end of the sunken area (Figs. 9 and 4).

The final profile, CA-R3 (Fig. 10), is $135 \mathrm{~m}$ long with 13 samples of soil air taken. The part of the profile in between $10-45 \mathrm{~m}$ lies in the forbidden area (see yellow hachure in Fig. 4), which should be the sunken area (Fig. 10). The terrain subsidence is clearly visible only in the part of 50$115 \mathrm{~m}$. The first point was measured in the non-undermined part and the radon concentration value of $5 \mathrm{kBq} \cdot \mathrm{m}^{-3}$ was registered (Figs. 11 and 4 ). The first increased value of radon concentration of nearly $24 \mathrm{kBq} \cdot \mathrm{m}^{-3}$ on $40 \mathrm{~m}$ fits perfectly with the boundary of undermined area (entering inside the 


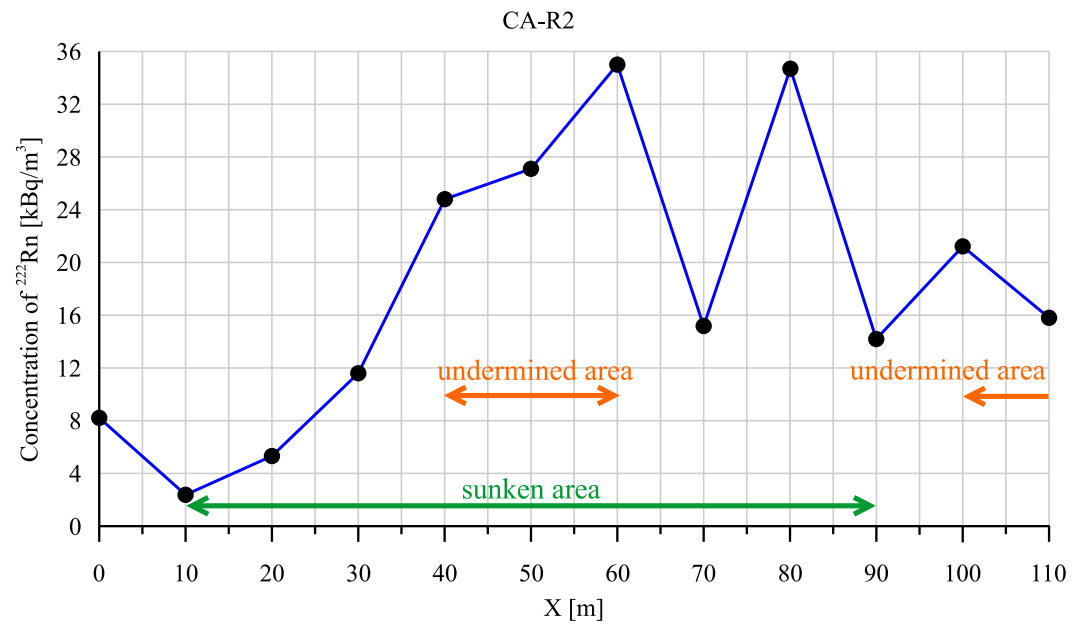

Fig. 8. Rn concentration values along CA-R2 profile (Andrássy, 2020).

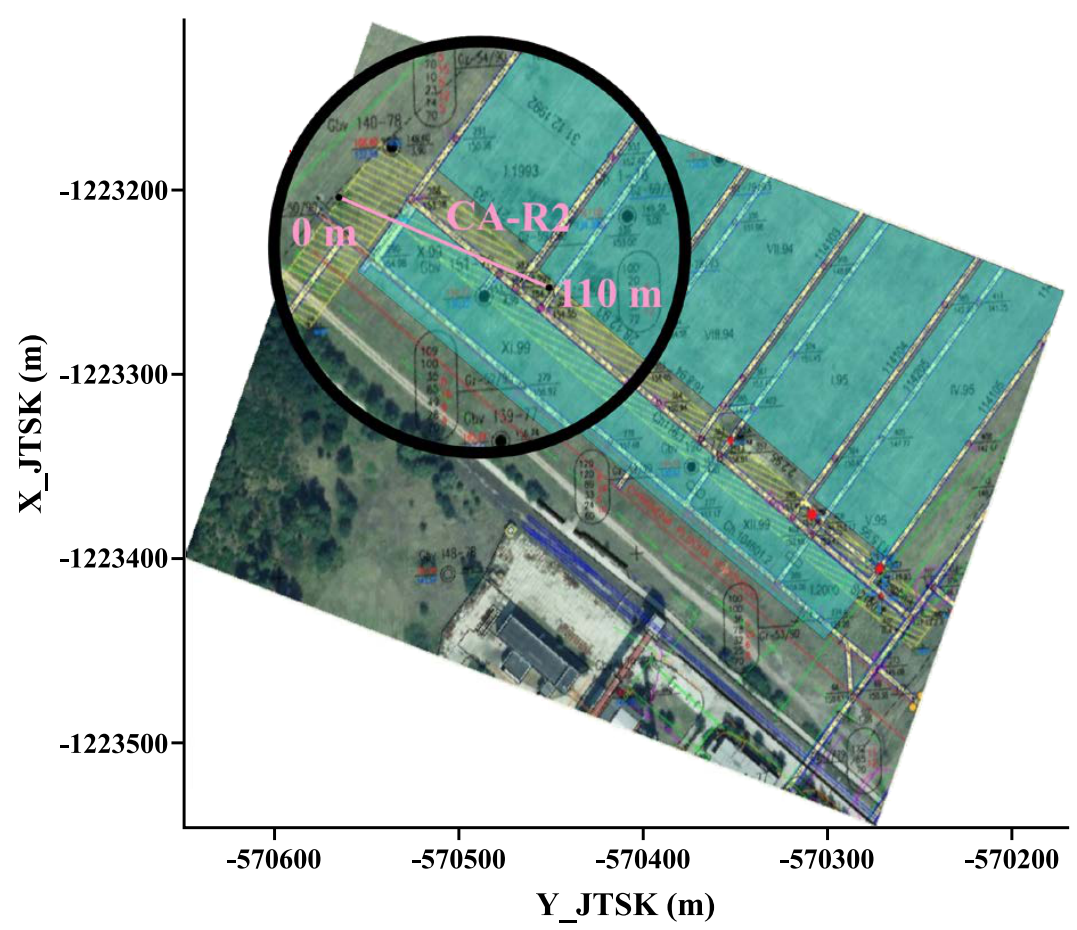

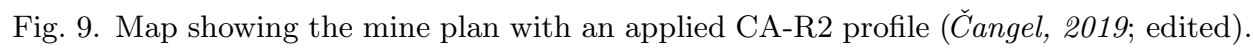




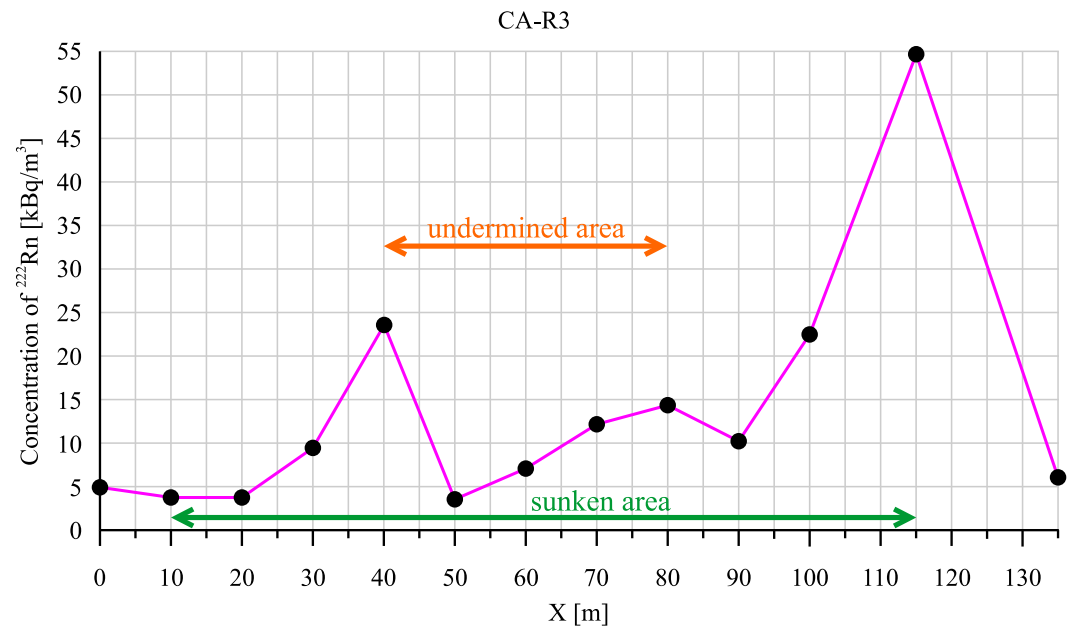

Fig. 10. Rn concentration values along CA-R3 profile (Andrássy, 2020).

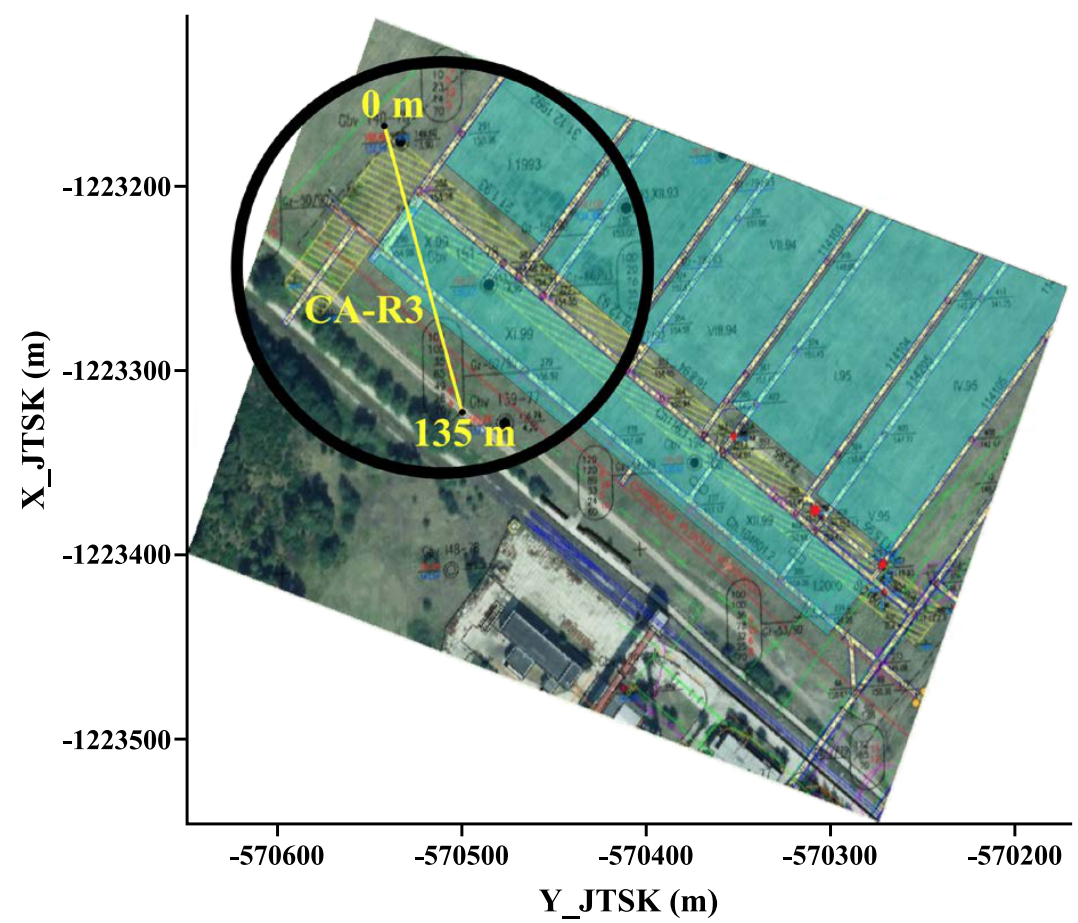

Fig. 11. Map showing the mine plan with an applied CA-R3 profile (Čangel, 2019; edited). 
area) and the next higher value of $14 \mathrm{kBq} \cdot \mathrm{m}^{-3}$ on $80 \mathrm{~m}$ again fits perfectly with the other boundary of the undermined area (leaving the area) (Figs. 11 and 4). The highest value of nearly $55 \mathrm{kBq} \cdot \mathrm{m}^{-3}$ on $115 \mathrm{~m}$ indicates the edge of the sunken area, similarly to the CA-R1 profile (Figs. 7, 11 and 4).

\section{Discussion}

The amount of radon in a pore, airy environment of rocks and soils depends on the amount of mother uranium present in the solid rock matrix and on the volume of the intergrain pore space. The formation and existence of large underground airy spaces, either as a result of natural tectonic and weathering processes (cracks, canals, caves), or anthropogenic activities (mining works, cellars, storages), can create good preconditions for accumulation of radon by its emanation from surrounding solid structural rock materials. It is documented by a number of scientific studies that deal with the evaluation of radiation load from radon exposure in tourist and healing-oriented caves (Szerbin, 1996; Thinová and Burian, 2008; Smetanová et al., 2014, 2020) or in operating mining works (Ayres da Silva et al., 2018), alternatively also in mining works which are in the state of activity suppression or liquidation (Wysocka et al., 2018). Health affecting radon accumulation occurs in these spaces mostly under the conditions of sufficient amount of uranium concentration in the surrounding geological materials (rocks) and media (underground water) and sufficient hermeticity of the underground space.

It seems that the first condition (sufficient amount of uranium concentration) is not met in the case of mined spaces in the studied Č́ry location. It is documented by a very low ${ }^{238} \mathrm{U}$ concentration values, average of $1.7 \pm 0.7 \mathrm{ppm}$ eU in comparison to the global average of 3-4 ppm eU in the Earth's crust (Mareš et al., 1990), which were discovered by a surface gamma-spectrometric research (Table 1, Fig. 12), which fully correlates with mostly sandy soil covers of the Záhorská nížina lowland. Adequately to low uranium concentration the lowest values of ${ }^{222} \mathrm{Rn}$ activity concentration (to approx. $8 \mathrm{kBq} \cdot \mathrm{m}^{-3}$ ) were discovered by profile emanometry above the original non-undermined or non-subsided areas - definitely on the first stations of CA-R1 and CA-R2 profiles and on the first and last stations of CA-R3 profile (Figs. 6-11). 
Table 1. Primary statistical parameters of gamma-spectrometric measurements of uranium concentration in Čáry location (Andrássy, 2020).

\begin{tabular}{|l|c|}
\hline Studied statistical parameters & eU $[\mathbf{p p m}]$ \\
\hline Total number of measured points & 21896 \\
\hline The lowest measured value & 0 \\
\hline The highest measured value & 6.5 \\
\hline Average & 1.7 \\
\hline Median & 1.6 \\
\hline Standard deviation & 0.7 \\
\hline
\end{tabular}

It also seems that regardless of anticipating a relatively good gas permeability of sandy-clay and coal formations building the studied area, the underground mined space displays a certain hermeticity and radon accumulation takes place in its volume. The detailed analysis and the correlation

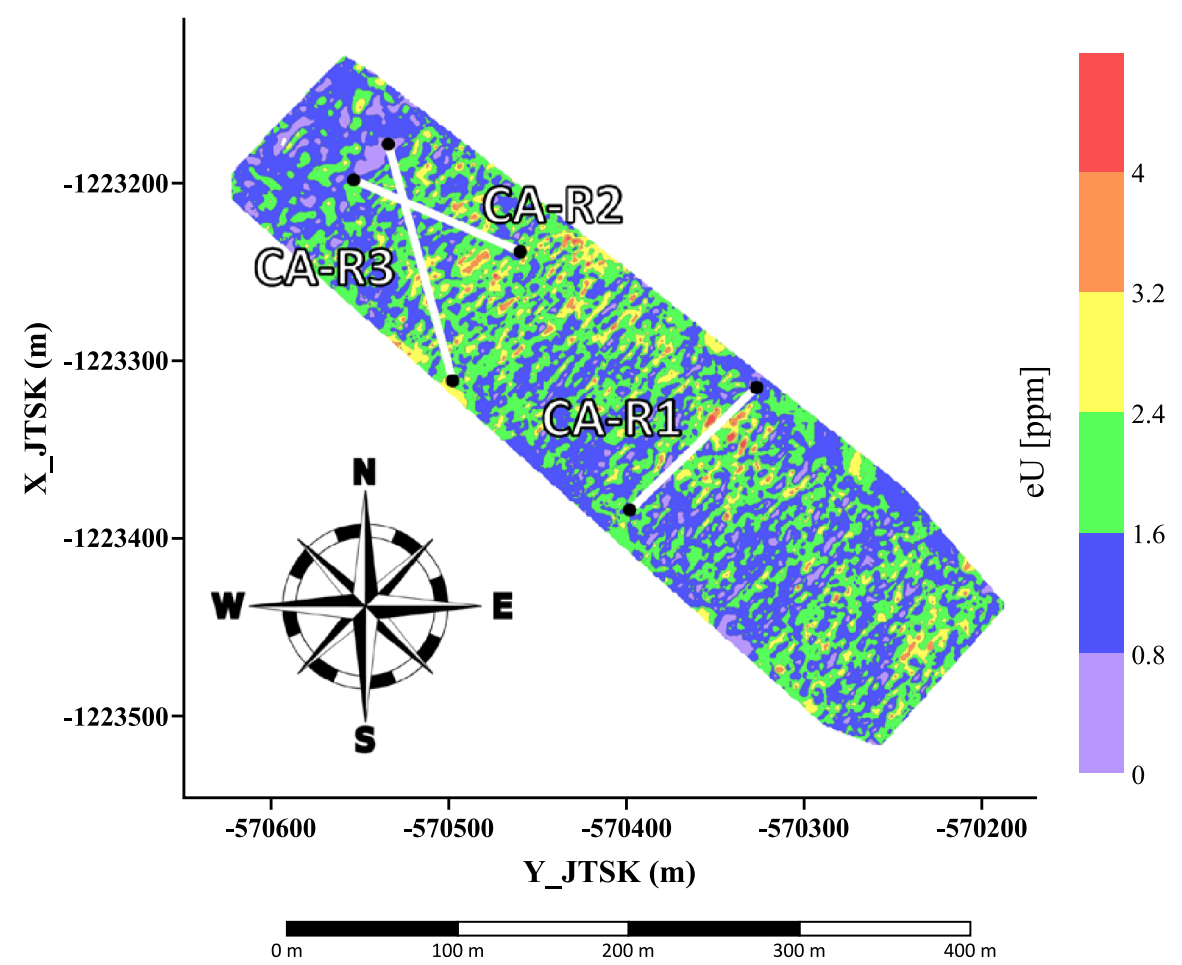

Fig. 12. Spatial distribution of uranium (Andrássy, 2020). 
between the location of single maxima of radon concentration along the profiles (Figs. 6, 8 and 10) and the spatial plan of undermined and subsided areas (Figs. 4, 7, 9 and 11) show they are in good agreement.

Individual anomalies of maximal values of ${ }^{222} \mathrm{Rn}$ activity concentration show clear relation to the boundaries (edges) of both undermined and subsided areas The localization of all important radon concentration anomalies (Table 2), shows a very good correlation with the localization of supporting mine walls of a mined space edge (Figs. 7, 9 and 11), which probably work as a vertical obstacle of radon spread in the undermined area and allow radon accumulation and vertical exit to the earth's surface. The majority of registered ${ }^{222} \mathrm{Rn}$ activity concentration anomalies in the soil air can serve as indicators of existing vertical underground supporting walls bordering and separating the empty mined space.

Table 2. Interpretation of important soil radon activity concentration anomalies.

\begin{tabular}{|l|c|c|l|}
\hline Profile & Station & $\left(\mathbf{k B q} \cdot \mathbf{m}^{-\mathbf{3}}\right)$ & Interpretation \\
\hline \multirow{3}{*}{ CA-R1 } & 15 & 34 & boundary of undermined and sunken area \\
\cline { 2 - 4 } & 60 & 10 & boundary of undermined area \\
\cline { 2 - 4 } & 85 & 16 & boundary of sunken area \\
\hline \multirow{4}{*}{ CA-R2 } & 40 & 25 & boundary of undermined area \\
\cline { 2 - 4 } & 50 & 27 & $\begin{array}{l}\text { very close to the boundary of undermined } \\
\text { area }\end{array}$ \\
\cline { 2 - 4 } & 60 & 35 & boundary of undermined area \\
\cline { 2 - 4 } & 80 & 35 & boundary of sunken area \\
\cline { 2 - 4 } CA-R3 & 100 & 21 & boundary of undermined area \\
\cline { 2 - 4 } & 40 & 24 & boundary of undermined area \\
\cline { 2 - 4 } & 80 & 14 & boundary of undermined area \\
\hline \multirow{3}{*}{} & 115 & 55 & boundary of sunken area \\
\hline
\end{tabular}

\section{Conclusions}

The method of soil radon emanometry was a part of a complex of surface geophysical methods used for the undermined area research on the Čáry brown coal mining field (Western Slovakia).

The field measurements confirmed the success of the used method in the identification of the undermined area and its inner division on the stud- 
ied site. Despite the characteristically low uranium content and relatively good gas permeability of the studied area built by sandy-clay formations, the measurements of ${ }^{222} \mathrm{Rn}$ activity concentration in soil air showed that at underground mined spaces' boundaries its accumulation occurs in amounts which, on the background of the non-undermined area values, signify registrable anomalies. The study showed that increased values of ${ }^{222} \mathrm{Rn}$ activity concentration in soil air can, in the case of the given geological structure, indicate the position of edge supporting mine walls and inner division of the underground mining space. Further research is intended to verify these conclusions in areas with different geological conditions.

Acknowledgements. This work was supported by the Scientific Grant Agency of the Ministry of Education, Science, Research and Sport of the Slovak Republic through VEGA 1/462/16 project and Slovak Research and Development Agency of Ministry of Education, Science, Research and Sport of the Slovak Republic through APVV-16-0146 project.

\section{References}

Andrássy E., 2020: Evaluation of Radioactivity and Electric Resistivity of Rock and Soil Environment in the Č́ry Area - Master Thesis. Comenius University in Bratislava. 89 p. (in Slovak, English abstract).

Ayres da Silva A. L. M., Eston S. M., Iramina W. S., Diegues Francisca D., 2018: Radon in Brazil underground mines. J. Radiol. Prot. 38, 2, 607-620, doi: 10.1088/1361-64 98/aaaf 45.

Czikhardt R., Papčo J., Bakon M., Liščák P., Ondrejka P., Zlocha M., 2017: Ground Stability Monitoring of Undermined and Landslide Prone Areas by Means of Sentinel-1 Multi Temporal InSAR, Case Study from Slovakia. Geosciences, 7, 3, 87, doi: 10.33 90/geosciences7030087.

Cangel O., 2019: Detection of Undermined Territory by Geophysical Methods on the Site Ban̆a Čary, a.s. - Master thesis. Comenius University in Bratislava. 85 p. (in Slovak, English abstract).

Fordinál K., Maglay J., Elečko M., Nagy A., Moravcová M., Vlačiky M., Kohút M., Németh Z., Bezák V., Polák M., Plašienka D., Olšavský M., Buček S., Havrila M., Hók J., Pešková I., Kucharič L., Kubeš P., Malík M., Baláž P., Liščák P., Madarás J., Šefčík P., Baráth I., Boorová D., Uher P., Zlinská A. Žecová K., 2012: Explanation to the Geological Map of the Záhorská Lowland (scale 1:50,000). State Geological Institute of Dionýz Štúr, Bratislava, 232 p. (in Slovak, English resume).

GCI \& NFC, 2017-2019: Geodetic and Cartographic Institute Bratislava \& National Forest Centre (Geodetický a kartografický ústav, Národné lesnícke centrum) (CGKÚ, NLC; yrs. 2017-2019, http://www.gku.sk/gku/, https://web.nlcsk.org/. 
Mareš S., Gruntorád J., Hrách S., Karous M., Marek F., Matolín M., Skopec J., 1990: Introduction to Applied Geophysics. SNTL, Praha, 680 p. (in Czech).

Mojzeš A., 2012: Field geophysical methods for rocksradioactivity measurement. Internal scripts for students of geology in Bachelors degree. Department of Applied and Environmental Geophysics, Faculty of Natural Sciences, Comenius University in Bratislava, 82 p. (in Slovak).

Negri S., Margiotta S., Quarta T. A. M., Castiello G., Fedi M., Florio G., 2015: Integrated Analysis of Geological and Geophysical Data for the Detection of Man-made Underground Caves in an area in Southern Italy. J. Caves Karst Stud., 77, 1, 52-62, doi: $10.4311 / 2014 \mathrm{ES} 0107$.

Smetanová I., Holý K., Zelinka J., Omelka J., 2014: Temporal variability of radon in the atmosphere of Domica and Važecká Karst caves (Slovakia). Radiat. Prot. Dosim., 160, 1-3, 65-69, doi : 10.1093/rpd/ncu097.

Smetanová I., Holý K., Luhová L., Csicsay K., Haviarová D., Kunáková L., 2020: Seasonal variation of radon and $\mathrm{CO}_{2}$ in the Važecká Cave, Slovakia. Nukleonika, 6, 2, 153157, doi: 10.2478/nuka-2020-0025.

Szerbin P., 1996: Natural radioactivity of certain spas and caves in Hungary. Environ. Int., 22, 1, 389-398, doi: 10.1016/S0160-4120(96)00137-7.

Šamajová L., Hók J., Csibri T., Bielik M., Teták F., Brixová B., Sliva L., Šály B., 2019: Geophysical and geological interpretation of the Vienna Basin pre-Neogene basement (Slovak part of the Vienna Basin). Geol. Carpath., 70, 5, 418-431, ISSN (print) 1335-0552, doi : 10.2478/geoca-2019-0024.

Thinová L., Burian I., 2008: Effective dose assessment for workers in caves in the Czech Republic: experiments with passive radon detectors. Radiat. Prot. Dosim., 130, 1, 48-51, doi : $10.1093 / \mathrm{rpd} / \mathrm{n} \mathrm{cn} 118$.

Wysocka M., Skubacz K., Chmielewska I., Bonczyk M., Urban P., Grycman J., 2018: Changes in radon emission in the area around the coal mine during closing process. In: Barnet I., Neznal M., Pacherová P. (Eds.): Proceedings of the 14-th International Workshop on the Geological Aspects of Radon Risk Mapping. Prague, September 17-21, 2018, 158-164, ISBN 978-80-01-06493-1.

Zahorec P., Pašteka R., Papčo J., Putiška R., Mojzeš A., Kušnirák D., Plakinger M., 2021: Mapping hazardous cavities over collapsed coal mines: Case study experiences using microgravity method. Near Surf. Geophys., 19, 3, 353-364, doi: 10.1002/nsg. 12139. 